\title{
Violence Against Native American Women in the United States
}

\author{
Jennifer DI PAOLO, University of Toronto, Canada
}

\begin{abstract}
I

$\mathrm{n}$ response to the topic of Global Justice and Human Rights: Country Case Studies, I will discuss the origin and continuation of violence against Native American women in the United States. In a report named Maze of Injustice: The Failure to Protect Indigenous Women from Violence by Amnesty International, the organization deemed the current status of violence against indigenous women one of the most pervasive yet hidden human rights abuses. The U.S Department of Justice has found that Native American and Native Alaskan women are 2.5 times more likely to be raped or sexually assaulted ${ }^{1}$. During an International Expert Group Meeting discussing Combatting Violence Against Indigenous Women and Girls, the United Nations Department of Economic and Social Affairs declared it a human rights issue of epidemic proportions. One in three Native American women are raped and three in five are physically assaulted. In reference to interracial violence, four out of five Native American victims of sexual assault reported that the perpetrator was white ${ }^{2}$. Unfortunately due to the shame and stigma surrounding topics such as sexual assault and rape it is estimated that in reality these numbers are far higher. Scholars and historians of pre-colonial Native societies have found that during this period women held prominent positions and violence against women was rare. With colonization came a radical change to the role of women in Native society. Gender based violence and the exclusion of women in important positions was a powerful tool used by British settlers to dismantle the structures of native society and ultimately conquer $i t^{3}$. Presently, due to the inadequate legal power given to Indian nations the crisis is not being dealt with efficiently. For example, Indian nations are unable to prosecute non-Indian offenders ${ }^{4}$. In my discussion of violence against Native women in the United States I will begin by analyzing its colonial origins. Next I will discuss why this violence persists today with reference to laws and judicial processes. Finally, I will discuss what must be done to end these human rights abuses.
\end{abstract}

\footnotetext{
${ }^{1}$ Amnesty International. Maze of Injustice: The Failure to Protect Indigenous Women from Violence in the USA (24 April 2007) http://www.amnesty.org/en/library/asset/AMR51/035/2007/en/ce2336a3-d3ad-11dd-a3292f46302a8cc6/amr510352007en.html (accessed December 20 2012)

${ }^{2}$ Henry, Terry. Addressing Violence Against Native American Women and Girls as a Human Rights Issue. United Nations Department of Economic and Social Affairs. Combatting Violence Against Indigenous Women and Girls: Article 22 of the United Nations Declaration on the Rights of Indigenous People (New York, January 2012)

http://www.un.org/esa/socdev/unpfii/documents/EGM12_Henry.pdf (accessed December 20 2012)

${ }^{3}$ Amnesty International. Maze of Injustice: The Failure to Protect Indigenous Women from Violence in the USA

${ }^{4}$ Henry, Terry. Addressing Violence Against Native American Women and Girls as a Human Rights Issue
} 
$I$ $\mathrm{n}$ a report named Maze of Injustice: The Failure to Protect Indigenous Women from Violence by Amnesty International, the organization deemed the current status of violence against Native women one of the most pervasive yet hidden human rights abuses of our time. The United States Department of Justice has found that Native American and Native Alaskan women are 2.5 times more likely to be raped or sexually assaulted. During an International Expert Group Meeting discussing Combatting Violence Against Indigenous Women and Girls, the United Nations Department of Economic and Social Affairs declared it a human rights issue of epidemic proportions. One in three Native American women are raped and three in five are physically assaulted. In reference to interracial violence, four out of five Native American victims of sexual assault reported that the perpetrator was white ${ }^{\mathrm{ii}}$. Unfortunately due to the shame and stigma surrounding topics such as sexual assault and rape it is estimated that in reality these numbers are far higher. Scholars and historians of pre-colonial Native societies have found that during this period women held prominent positions and violence against women was rare. With colonization came a radical change to the role of women in Native society. A gender based hierarchy, violence, and an attack on the important role of Native motherhood were powerful tools used by British settlers to dismantle the structures of Native society and ultimately conquer it ${ }^{\text {iii }}$. Presently, due to the diminution of Native sovereignty and the subsequent inadequate legal power given to Indian nations the crisis is not being dealt with efficiently. Despite these limitations, the recent developments in laws pertaining to Native women and various organizations and initiatives created by female Native activists have made progress for the safety of Native women. In this discussion of violence against Native women in the United States we will begin by analyzing women's role in traditional Native society. Then we will investigate the colonial origins of violence against Native women. Next we will discuss why this violence persists today with reference to laws and judicial processes. Finally, we will discuss what female Native activists are doing to combat the problem and the most efficient solutions to these issues.

We must begin our analysis of violence against Native women by addressing the question of what role Native women had in traditional society. Although the position of women in Native society differed from tribe to tribe there are many common characteristics among them. Overall, women held a complementary role to men instead of a secondary one ${ }^{\mathrm{iv}}$. Native society was built on beliefs and practices that made up an integral part of their culture such as the belief of respect and safety, which protected all Native people, including women, from violence. The relationship between men and women within Native families was built on these beliefs of safety and respect and mothers played an important role within the family, culture, society, and economy ${ }^{\mathrm{v}}$. Native mothers were a part of the economic system because they had control over the home, food production, trade, and the distribution of resources ${ }^{\mathrm{vi}}$. Although there was a division of labour between men and women this division was not used to oppress women 
because the labour of both genders was seen as equally valuable ${ }^{\text {vii }}$. Some Native societies such as the Iroquois were matrilineal and in these societies mothers held very powerful positions such as acting as clan mothers. Some other rights that Native women enjoyed were the right to separate from their husband and keep their property and owning most or all of the land including the house and animals ${ }^{\text {viiix }}$. Women were political, military, and spiritual leaders ${ }^{\mathrm{x}}$. Despite the absence of an over arching patriarchal system like that of Europe, gendered violence did happen within Native society. However, according to oral and written records these occurrences were very rare and the perpetrators often faced severe and public punishment, displaying how much respect and safety was built into Native society ${ }^{x i}$. It is difficult to understand how gendered violence towards Native women went from a rarity to something that occurs at a rate higher than any other group of women in America.

The root of violence against Native women can be traced back to the conquest of America. During conquest European colonists instilled a gendered hierarchy within Native society, employed violence, and attacked Native motherhood. Europeans did not understand the powerful role of women in Native society because European society was far more patriarchal $^{\text {xii }}$. For the Europeans, dismantling the egalitarian role of women in Native society was a way of dismantling Native social structures. During conquest Natives were coerced into abolishing their system of governance including the system of traditional laws and beliefs that kept Native women safe. Europeans believed that the status of women in Native society was uncivilized and that instituting a gendered hierarchy was a part of the process of civilization ${ }^{x i i i}$. One way in which this hierarchy was achieved was through the refusal of European colonists in negotiating with Native women. For example, despite the number of female Chiefs and councilors, men signed all of the historic treaties, which greatly undermined the role of women in political leadership ${ }^{\text {xiv }}$. Christian missionaries also pushed for the performance of their view of correct gender roles $^{\mathrm{xv}}$. These roles were different from the spiritual views that Natives held and were used to oppress Native women. Furthermore, Christianity suppressed sexual freedom in sexually liberal Native societies such as the Cherokee ${ }^{\mathrm{xvi}}$. Sexual violence was another tool of conquest, which was displayed in the records of Russian soldiers in Alaska employing sexual violence towards Native women. In response to this, Native Alaskan men attempted to defend Native women from this violence displaying their devotion to maintaining the safety and respect of women in their community ${ }^{\text {xvii. }}$. In contrast to the use of sexual assault as a tool of war, it was rare that Natives used sexual violence towards white prisoners ${ }^{\text {xviii }}$. Another violent method used by colonists was clearing the land, which was usually done through relocating entire communities to an area more accommodating for the colonists. Removal and relocation led to the loss of customary land, the lifestyles that 
Natives had built on that land, economic downturn, and disparity ${ }^{\text {xix }}$. Laws created by the United States government changed individual rights pertaining to property, which created drastic changes within matrilineal societies. Not only did women lose their control over resources, they also lost control over domestic and voting rights ${ }^{\mathrm{xx}}$. Despite these atrocities, the implementation of a gender hierarchy and the use of violence during conquest were not as vicious and hurtful as the colonial attack on Native motherhood.

Due to the important role that mothers played in Native society as economic decision makers, clan mothers, and property owners, it is no surprise that the colonists attacked Native motherhood during colonization. The two ways in which the colonists did this was through residential schooling and forced sterilization. In the boarding school era of 1880-1950, residential schooling would become one of the strongest forms of forced assimilation. In this era Native children as young as five years old were taken from their homes and families to attend residential schools until age $18^{\mathrm{xxi}}$. The first boarding school was named The Carlisle Indian School and was created by Captain Richard Henry Pratt in 1879. Initially this school had no support from the American government but in 1891 after Pratt had lobbied the government extensively, funding and support was given to open more boarding schools. The separation of Natives from their homes was thought to be vital to the assimilation process. Not surprisingly, Native parents desperately attempted to resist sending their children to boarding schools but Congress allowed the
Commissioner of Indian Affairs to make rules ensuring attendance. There were also harsh consequences for parents who did not allow their children to attend these schools. For example, Native parents underwent coercion such as the rationing of food for their tribes, which ensured that parents would have to choose between starving their child or sending them to boarding school with the hopes that they would be fed well. Despite this hope, the living conditions in residential schools were no better than in poverty stricken reserves. Boarding schools were unsanitary, children had to perform labour intensive work, and they provided poor nutrition. The combination of these living conditions bred disease and illness. The conditions of the residential schools were cruel and inhumane and native children were subjected to emotional, physical, spiritual, and sexual violence. At residential schools Native children were not allowed to practice their language or culture and instead were taught about European history, culture, and the English language. Many Native children lost their spirituality in the forced conversion to Christianity ${ }^{x x i i}$. This was important for Native women because although Native spirituality was egalitarian, Christianity is patriarchal. Upon returning home, Natives felt alienated because they could not understand the language or culture and because they had been taught that Native culture was inferior to American culture. Many Natives that had grown up in residential schools were unable to become adequate parents in terms of passing down their culture, language, spirituality, or lifestyle to their children. Residential 
schooling dismantled the empowered traditional position of motherhood in Native society in three ways. First, by taking children away from the guidance of their mothers to force them into residential schooling where they lost their language and culture. Second, by ensuring that women that grew up in residential schools would be unable to properly mother their children because of emotional and psychological issues. The effect that boarding schools had on the mental health of Natives led to mental health conditions and a reliance on alcohol. These two issues combined with a lack of the ability to be good parents led to the removal of Native children from their homes to be placed in foster care or adoption. This continued the cycle of removing Native children from their mothers and is the third way that the role of the Mother in Native society had been forever changed ${ }^{\text {xiii }}$.

The next way in which the colonists attacked Native motherhood was through forced sterilization. Although women of many minority groups in America underwent forced sterilization in the 1970s, there was something unique about Native women in that they were much more dependent on the federal government. This dependence was specifically in relation to the Indian Health Service, the Department of Health, Education, and Welfare, and the Bureau of Indian Affairs $^{\text {xxiv }}$. Between 1973 and 1976, Indian Health Service clinics sterilized 3,406 Native women. It is difficult to determine if Native women were thoroughly informed of the procedure and truly consented to it. There was not a standard consent form used for every patient and most of the forms used for Native patients did not abide by government regulations of informed consent. Furthermore, it is unknown if adequate counseling was provided before sterilization procedures. Some Native tribes such as the Navajo provided counselors but areas such as South Dakota, Montana, and Oklahoma did not have counselors and only the doctor was present during the sterilization procedure. Various law suits have been filed in reference to these flawed sterilization procedures. Michael Zavalla is a lawyer that represented three Native women from Montana in a class action lawsuit against the Department of Health, Education, and Welfare. This litigation was based on the evidence that these women were sterilized without consent or being fully informed of the operation. It was filed against hospital doctors who forced Native women into sterilization by suggesting that if they did not undergo the process they would lose access to welfare benefits, that the surgery was unavoidable, or worse, that it could be reversed if needed. The case did not go to trial but it was settled through compensation on the agreement that the plaintiffs' identity and the details of the case would remain undisclosed. After learning of this case and others, a judge from the Northern Cheyenne Reservation named Marie Sanchez decided to conduct her own inquiry into the cases of sterilization within her tribe. The results she obtained were unsettling. Between 1973 and 1976, two girls under 15 years of age were sterilized under the false pretense that they were getting their appendices removed. Another woman 
underwent a hysterectomy after being convinced by her physician that the migraines she was suffering from would be cured by it. It was discovered at a later time that the source of her problem was actually a brain tumour. Forced sterilization undermined the ability of Native women to reproduce, disabling them from creating the next generation to maintain their beliefs, culture, and traditions ${ }^{\mathrm{xxv}}$. Sterilization also has destructive effects on the survival of an entire tribe ${ }^{\mathrm{xxvi}}$. Women that were misinformed or coerced into sterilization were denied basic reproductive rights and more importantly, control over their own body. For these reasons, sterilization was a direct attack on the traditionally powerful role of Native motherhood.

Next we will investigate the legal relationship between Natives and the federal government. Through a gradual process of diminishing Native selfgovernment and the sovereignty of Native jurisdiction, Native women have been separated from any other group of American women and it has become increasingly difficult for Native tribes to protect them ${ }^{\text {xxvii }}$. This legal relationship has made Native women the most oppressed group of women in America and the least protected legally. In our investigation of the legal relationship between Native tribes and the federal government we will analyze the Major Crimes Act of 1885, Public Law 280 of 1953, the Indian Civil Rights Act of 1968, and the Oliphant V. Suquamish case.

The Major Crimes Act of 1885 allowed the American government to assume complete jurisdiction over severe crimes committed by Native Americans in Native Country ${ }^{\text {xxiii }}$. The crimes deemed severe were murder, kidnapping, assault, and sexual abuse $e^{\text {xix }}$. This Act has restricted the ability of Native tribes to exercise jurisdiction within their own reserves thus threatening their self-governance and sovereignty ${ }^{x x x}$. The basic premise for federal control over Native jurisdiction rests upon the dependence of Native tribes on the American government despite the reality that many Native tribes posses their own government, police force, and judicial system. Federal response to Native crime is slow and inadequate and Native prosecution would be much more efficient. Native police and judicial systems are superior in investigating and prosecuting crimes that occur within their tribes because of their proximity to the crimes and their knowledge of the nature of Native crime $^{\text {xxxi }}$. The Major Crimes Act has facilitated violence against Native women because it has allowed the American government to assume control over jurisdiction of crimes that disproportionately affect women ${ }^{\text {xxii }}$. The inefficiency of the federal government in their response and investigation of major crimes committed in Native Country has become an inefficiency related to crimes against women. Public Law 280 was enacted in 1953 and altered the laws of the Major Crimes Act in some states. This law shifted the control of the Federal government over Native jurisdiction to the state governments within California, Minnesota, Nebraska, Oregon, Washington and Alaska in 1958. The rest of the states were given the option to adopt Public Law 280 if and when so chose ${ }^{\text {xxxiii. }}$. The shift from federal to state government occurred 
with no contribution or consent from the Native tribes and Native Americans rightly saw it as another threat to their self-governance ${ }^{\text {xxiv }}$. A major reason Public Law 280 was passed was to decrease federal spending ${ }^{\mathrm{xxv}}$. However, in this process the federal government did not supply money to state governments to fund law enforcement activities leading to even more deficiency in these areas. Moreover, the Bureau of Indian Affairs decreased funding to Native authorities because of the transfer from federal to state government ${ }^{\mathrm{xxxi}}$. Native women were negatively affected once again because of the decrease in funding for dealing with crimes that fall under the Major Crimes Act and Public Law 280.

The Indian Civil Rights Act of 1968 allowed Native tribal government jurisdiction over some criminal procedures and the protection of other basic rights including due process of law. Supposedly, it was created to protect Natives from civil rights abuses inflicted upon them by their tribes ${ }^{\text {xxxvii }}$. However, many Native tribes did not see the ICRA as a Bill of Rights designed to protect Natives but as another attack on their sovereignty ${ }^{\text {xxxiii }}$. Certain policies within the Indian Civil Rights Act had once again restricted their ability to respond to crime. Tribal courts were restricted from imposing a penalty of more than one year and a five thousand dollar fine for any one offence. These offences could include murder or rape, two crimes that effect Native women at an alarming rate ${ }^{\mathrm{xxix}}$. This undermined the ability of tribal courts in responding adequately to serious crimes and in protecting Native women from these crimes.
The next case that threatened the protection of Native women was the Oliphant V. Suquamish Indian Tribe decision. The plaintiffs of this case were arrested by tribal police on the Suquamish reserve. Both plaintiffs wanted to be tried under habeas corpus in federal courts but they were denied this request and their case went to the Supreme Court ${ }^{\mathrm{xl}}$. The ruling that came out of this case was that Native tribes are unable to prosecute non-Natives. The reasons given for this ruling were that the reserve was given to the Suquamish Tribe by the federal government, that the state of Washington had funded the creation of their schools, roads, and other public property, and that there were far more non-Natives in this area than Natives. This ruling has had disastrous effects on the safety of Natives because both the federal and state governments have proven to be inefficient in prosecuting crimes pertaining to Natives. This is due to the lack of resources and desire to respond efficiently and promptly to Native crime $^{\mathrm{xli}}$. This ruling has left Native women susceptible to danger imposed on them by non-Natives, which is startling due to the high percentage of violence imposed on Native women by non-Native perpetrators. For example, four out of five Native victims of sexual violence claim that the assaulter was white ${ }^{\text {xlii }}$. This decision structurally prevents protection for Native women against the interracial violence they endure.

The legal initiatives that we have explored so far have led to a serious deficiency in protecting Native women against violence. The Major Crimes Act restricted tribal jurisdiction over severe 
crimes that disproportionately affect women, thus separating Native women from other American women. Public Law 280 transferred this power from the federal government to the state government in certain states without providing sufficient funding leaving Native women even more unprotected. The Indian Civil Rights Act gave Natives a Bill of Rights but limited tribal governments from employing serious punishments to perpetrators of major crimes. Finally, protection for Native women against violence inflicted on them by non-Native men was diminished in the Oliphant V. Suquamish decision. These Acts and decisions have impacted the services and programs provided to Native women. The increase in psychological and physical illnesses is a demonstration of the negative effects that violence has had on Native women. Studies have shown that Native women experience a higher rate of Post Traumatic Stress Disorder, alcohol abuse, suicide and various other mental illnesses than any other group of women. Although it is proven that Native women experience sexual and physical violence at a greater rate than women of any other race, there is still a serious lack of research on the physical and psychological effects of these crimes. What is distinct in the situation of Native women is the historical trauma endured by Native Americans within their relationship with the federal government. Historical trauma includes intergenerational and societal oppression that is historical and ongoing ${ }^{\text {xliii }}$. The policies of stripping away the power of tribal court systems over crimes related to Native women coupled with the federal and state governments insufficiency in dealing with Native crime has left Native women unprotected, alienated, and distrustful. Two recent Acts that have somewhat responded to these issues and have improved the protection of Native women against violence are the Violence Against Women Act of 2005 and the Tribal Law and Order Act of 2010.

The Violence Against Women Act passed in 2005 is the first of the two most recent acts that have sought to diminish violence against Native American women. Due to the policies within this act, for the first time Native tribes have gained access to valuable resources that can combat violence against Native women in their communities. It is especially helpful for aiding domestic violence, sexual violence, and stalking. Not only does it allow access to new resources but it also recognizes the sovereignty of tribal responses to these crimes ${ }^{\text {liv }}$. The second contemporary act that has made a positive impact on the lives of Native women is the Tribal Law and Order Act of 2010. This act includes policies that will help Native survivors of sexual and domestic violence. Some of the specific sections within this Act that pertain to victims of sexual and domestic violence are sections 261, 262, 264, and 266. Section 261 gives tribal government modes of amending the criminal system and the ability to track federal offenders. By ameliorating the criminal system, tribal governments will be able to deal with perpetrators of violence more efficiently. Increasing the ability to track federal offenders will reverse some of the negative affects of the Oliphant V. Suquamish decision and will aid in the protection of Native 
women against non-Native perpetrators. Section 262 gives tribal police more efficient methods of questioning victims and obtaining evidence. It also ameliorates the services provided to victims by extending the U.S Department of Justice sexual assault procedures to Native health clinics. This policy helps in decreasing the alienation of Native women from non-Native women by providing them with the same standard in sexual assault assistance. Section 264 increases the services and programs for Native American victims of assault and it seeks to decrease the amount of Native women that are trafficked for sex work. This addresses the very serious issue of sex trafficking by working to protect and decrease the number of Native women that are negatively affected by it. Lastly, section 266 enhances the ability of the Indian Health Services to respond to sexual and domestic violence in remote areas. This is especially helpful in protecting Native women that live in isolated tribes and have difficulty traveling to federal health clinics or seeking federal legal action ${ }^{\mathrm{xlv}}$. Overall, it has attempted to increase the services and programs available for Native women to a level comparable to those available for other women within the United States.

Despite the overwhelming amount of structural ways in which violence is inflicted against Native American women it would be discouraging and incomplete to ignore the progressive work that Native female activists have done in regards to combatting this violence. Although there are numerous exceptional Native female activists, we will be focusing on three scholars that embody Native feminism: Renya Ramirez, Andrea Smith, and Luana Ross. Renya Ramirez is a member of the Winnebago Tribe of Nebraska. She advocates that Natives need to consider fighting violence against Native women a priority in ameliorating the overall status of Native communities. Ramirez argues that this must be done by considering racial, tribal, and gender issues as intersectional and nonhierarchical. She believes feminism is an important ideology to spread within Native communities ${ }^{\text {xlvi }}$. Next is Andrea Smith, an activist and scholar from the Cherokee nation. Smith advocates ending gendered violence as a means of survival for Native tribes. She views the abolishment of the power held by Native women as simultaneous to the abolishment of Native sovereignty. Smith sees the value in creating a Native criminal justice system separate from the state because the state has created many problems within the Native community ${ }^{x v i i}$. Andrea Smith has also organized the Colour of Violence: Violence Against Women of Colour Conference to combat violence against women of colour specifically because it is often over looked in academia and activism. This conference serves as an open forum for women of colour, including Native women, to converse about the violence they face ${ }^{x l v i i i}$. An initiative that came out of this conference and that was co-organized by Smith is INCITE! Women of Colour Against Violence. This organization is comprised of feminists of colour and it works on intersectional issues pertaining to state violence, sexual, and domestic violence. It 
functions as a grass roots organization instead of using social service methods ${ }^{x l i x}$. Lastly is Luana Ross, a keynote speaker at the first Colour of Violence Conference and another phenomenal Native female activist. During her speech she called on Natives to use traditional views of sovereignty to protect Native women against violence instead of depending on the federal government for assistance. She also advocated for full tribal jurisdiction over crimes relating to Native women. Ross was born in Flathead Indian Reservation in Montanali. In the 1980 s she began organizing retreats for Native women to help them heal from violence. These retreats became a forum for women to speak to each other and female counselors about the violence they endured. She also gave presentations to reserves about the importance of feminism and gave Native women the opportunity to speak about their experiences with violence. This is important because during the $80 \mathrm{~s}$ violence was entrenched in Native society and even normalized. Ross addresses an important issue in her work that is not easy to quantify by research. This issue is the desire of Native women to shield Native men from the federal criminal justice system because it is viewed as another form of colonialism. For this reason, it is difficult to know exactly how many Native women are subjected to violence. Ross advocates for the power of feminism and for connecting Native feminism to the larger feminist community. She directly connects the increase of domestic violence programs for Native women and the new openness for discussion about violence to Native feminism ${ }^{\text {lii }}$. Ross' work empowers women through storytelling and advocacy and promotes Native tribal sovereignty.

By analyzing female Native activists one can view the progress that is being made within Native communities in terms of creating organizations and conferences to analyze and attack these issues, theorizing about solutions, and creating safe spaces for Native women to speak about the violence that they have endured. The complexity of the issue of violence inflicted upon women coupled with the cultural differences between Native tribes makes it difficult to establish a set of blanket guidelines to eradicate this problem. However, after analyzing the reasons and responses behind violence against Native women in the United States we can conclude with three viable solutions. The three solutions that would make profound differences in the protection of Native women would be the establishment of tribal sovereignty, increasing awareness surrounding this issue, and the empowerment of Native women. Tribal sovereignty is the most obvious solution to this and numerous other problems that Native Americans face. By allowing tribes to have legal authority over their own affairs, the traditional spiritual and political role of Native women can be re-established. Tribes will be able to respond to crime in a manner that is non-assimilative and corresponds with their culture, which will ultimately end the colonial legacy of federal control over Native crime especially those crimes that affect Native women at alarming rates such as murder, rape, kidnapping, and stalking. Moreover, it would work to reverse 
some of the negative affects of colonialism. The next solution is ending the silence surrounding the injustices suffered by all Native Americans with an emphasis on those endured by Native women. This can be done by garnering more research with respect to the issues discussed and by ensuring that the methods of attaining this research is engineered in a way that properly examines Native culture and life. The final solution is empowering Native woman. This would include ensuring that Native women are able to resume powerful roles in society through adequate education and health services especially safe reproductive services. This would also include allowing extensive access to resources for Native women activist organizations so that they can uplift women in every Native community. Ensuring that women have the resources they need to address issues pertaining to their specific community will lead to the most positive and efficient change for Native women.

${ }^{i}$ Amnesty International, "Maze of Injustice: The Failure to Protect Indigenous Women from Violence in the USA" (Amnesty International Publications, 2007) accessed December 2012 http://www.amnestyusa.org/ourwork/issues/women-s-rights/violenceagainst-women/maze-of-injustice

${ }^{i i}$ Terry Henry. "Addressing Violence Against Native American Women and Girls as a Human Rights Issue" (New York, United Nations Department of Economic and Social Affairs, January 2012) 1 http:/ /www.un.org.myaccess.library.utoront o.ca/esa/socdev/unpfii/documents/EGM1 2_Henry.pdf

iii Amnesty International "Maze of Injustice: The Failure to Protect Indigenous Women from Violence in the USA"

iv Laura F. Klein and Lillian A. Ackerman eds. Women and Power in Native North America (USA: University of Oklahoma Press, Norman, 1995) 236

v Sarah Deer, Bonnie Clairmont, Carrie A. Martell and Maureen L. White Eagle eds. Sharing Our Stories of Survival: Native Women Surviving Violence. Tribal Legal Studies, ed. Gardner, Jerry (Plymouth, U.K:AltaMira Press, 2008) 5

${ }^{\text {vi }}$ Ibid., 8

${ }^{v i i}$ Andrea Smith. Conquest: Sexual Violence and American Indian Genocide. (Cambridge, MA: South End Press, 2005) 18

viii Roe Bubar and Pamela Jumper Thurman "Violence Against Native Women" Social Justice 31, no.4 (2004) accessed January 1 2013,

http://www.jstor.org.myaccess.library.utoro nto.ca/stable/29768276

${ }^{i x}$ Hilary Weaver "The Colonial Context of Violence: Reflections on Violence in the Lives of Native American Women" Journal of Interpersonal Violence 24, no. 9 (September 2009) accessed January 27 2013, 1554 http://journals2.scholarsportal.info.myacces s.library.utoronto.ca/tmp/113619194713538 92927.pdf

${ }^{x}$ Andrea Smith Conquest: Sexual Violence and American Indian Genocide 18

${ }^{\text {xi }}$ Ibid., 12

xii Ibid., 17

xiii Sarah Deer, Bonnie Clairmont, Carrie A. Martell and Maureen L. White Eagle eds. Sharing Our Stories of Survival: Native Women Surviving Violence. 8

xiv Hilary Weaver "The Colonial Context of Violence: Reflections on Violence in the Lives of Native American Women" 1555

xv Amnesty International "Maze of Injustice: The Failure to Protect Indigenous Women from Violence in the USA" 
${ }^{\text {xvi }}$ Laura F. Klein and Lillian A. Ackerman eds. Women and Power in Native North America, 241

xvii Sarah Deer, Bonnie Clairmont, Carrie A. Martell and Maureen L. White Eagle eds. Sharing Our Stories of Survival: Native Women Surviving Violence. 11

xviii Andrea Smith Conquest: Sexual Violence and American Indian Genocide, 18

xix Roe Bubar and Pamela Jumper Thurman

"Violence Against Native Women" 73

${ }^{\mathrm{xx}}$ Ibid., 240-241

xxi Amnesty International "Maze of Injustice: The Failure to Protect Indigenous Women from Violence in the USA"

xxii Ann Murray Haag "The Indian Boarding School Era and its Continuing Impact on Tribal Families and the Provision of Government Services" Tulsa Law Review 43 (2007-2008) accessed February 16 2013, 151 154

http://simplelink.library.utoronto.ca/url.cf $\underline{\mathrm{m} / 342749}$

xxiii Ibid., 157-161

xxiv Sally J. Torpy "Native American Women and Coerced Sterilization: On the Trail of Tears in the 1970s" American Indian Culture and Research Journal 24, no.2 (October 1 2007, 2000) accessed February 16 2013, 1 http://simplelink.library.utoronto.ca/url.cf $\underline{\mathrm{m} / 342753}$

${ }_{\mathrm{xxv}}$ Ibid., 7-9

xxvi Ibid., 11

xxvii Sarah Deer, Bonnie Clairmont, Carrie A. Martell and Maureen L. White Eagle eds. Sharing Our Stories of Survival: Native Women Surviving Violence. 11

xxviii Warren Stapleton. "Indian Country, Federal Justice: Is the Exercise of Federal Jurisdiction Under the Major Crimes Act Constitutional?" Arizona State Law Journal 29 (1997) accessed February 17 2013, 337 http://simplelink.library.utoronto.ca/url.cf $\mathrm{m} / 342756$

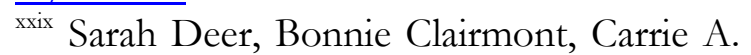
Martell and Maureen L. White Eagle eds. Sharing Our Stories of Survival: Native Women Surviving Violence, 13

xxx Warren Stapleton. "Indian Country, Federal Justice: Is the Exercise of Federal
Jurisdiction Under the Major Crimes Act Constitutional?" 339

xxxi Ibid., 341-342

xxxii Sarah Deer, Bonnie Clairmont, Carrie A. Martell and Maureen L. White Eagle eds. Sharing Our Stories of Survival: Native Women Surviving Violence, 13

xxxiii Ross Naughton "State Statutes Limiting the Dual Sovereignty Doctrine: Tools for Tribes to Reclaim Criminal Jurisdiction Stripped by Public Law 280" UCLA Law Review 55, (2007-2008) accessed February 17 2011, 494-6 http://simplelink.library.utoronto.ca/url.cf $\underline{\mathrm{m} / 342757}$

xxxiv Ibid., 491-492

xxxv Ibid., 497

xxxvi Amnesty International "Maze of Injustice: The Failure to Protect Indigenous Women from Violence in the USA"

xxxvii Jennifer S. Byram. "Civil Rights on Reservations: The Indian Civil Rights Act \& Tribal Sovereignty" Oklahoma City University Law Review 25 no. 1,2 (2000) accessed February $18 \quad 2013, \quad 494-496$ http://simplelink.library.utoronto.ca/url.cf $\mathrm{m} / 342760$

xxxviii Carla Christofferson. "Tribal Courts Failure to Protect Native American Women: A Reevaluation of the Civil Rights Act" Yale Law Journal 101 (1991-1992) accessed $\begin{array}{llll}\text { February } & 18 & 2013, & 171\end{array}$ http://simplelink.library.utoronto.ca/url.cf $\mathrm{m} / 342761$

xxix Amnesty International "Maze of Injustice: The Failure to Protect Indigenous Women from Violence in the USA"

xl Judith V. Royster "Oliphant and its Discontents: An Essay Introducing the Case for Reargument Before the American Indian Nations Supreme Court" Kansas Journal of Law and Public Policy 13, no. 1 (2003-2004) accessed February 18 2013, 59 http://simplelink.library.utoronto.ca/url.cf $\mathrm{m} / 342763$

xli Ibid., 60-61

slii Terry Henry. "Addressing Violence Against Native American Women and Girls as a Human Rights Issue" 1 
xliii Angela Gebhardt, Jane Woody. "American Indian Women and Sexual Assault: Challenges and New Opportunities" Affilia: Journal of Women and Social Work 12, No. 3 (August 2012) accessed February 18 2013, $238-240$ doi:10.1177/0886109912452642.

xliv Sarah Deer, Bonnie Clairmont, Carrie A. Martell and Maureen L. White Eagle eds. Sharing Our Stories of Survival: Native Women Surviving Violence, 19

xlv Angela Gebhardt, Jane Woody. "American Indian Women and Sexual Assault: Challenges and New Opportunities" 241

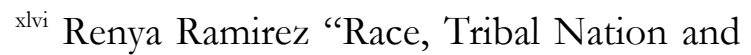
Gender: A Native Feminist Approach to Belonging" Meridians: Feminism, Race, Transnationalism 7 no. 2 (January 1 2007) accessed February 19 2013, 22 doi:10.2979/MER.2007.7.2.22.

xlvii Andrea Smith Conquest: Sexual Violence and American Indian Genocide, 138-139

xlviii Renya Ramirez "Race, Tribal Nation and Gender: A Native Feminist Approach to Belonging" 27-28

xlix Andrea Smith Conquest: Sexual Violence and American Indian Genocide, 2

${ }^{1}$ Renya Ramirez "Race, Tribal Nation and Gender: A Native Feminist Approach to Belonging" 28

li Luana Ross "From the "F" Word to Indigenous/Feminisms" Wicazo Sa Review 24, no.2 (October 2009) accessed February 19 2013, 43 doi:10.1353/wic.0.0041

lii Ibid., 45
Bibliography

Amnesty International. "Maze of Injustice: The Failure to Protect Indigenous Women from Violence in the USA." Amnesty International Publications (2007), accessed December 20, 2012, http://www.amnestyusa.org/ourwork/issues/women-srights/violence-against-women/mazeof-injustice

Bubar, Roe and Pamela Jumper Thurman. "Violence Against Native Women." Social Justice 31, no. 4(98) (2004): 26/01/2013-70-86.

http://www.jstor.org.myaccess.library .utoronto.ca/stable/29768276

Byram, Jennifer S. "Civil Rights on Reservations: The Indian Civil Rights Act \& Tribal Sovereignty." Oklahoma City University Law Review 25, no. 1,2 (2000): February 18 2013-491-509. http://simplelink.library.utoronto.ca/ url.cfm $/ 342760$

Christofferson, Carla. "Tribal Courts Failure to Protect Native American Women: A Reevaluation of the Civil Rights Act." Yale Law Journal 101, (19911992): February 18 2013-169-185. http://simplelink.library.utoronto.ca/ url.cfm/342761

Deer, Sarah, Bonnie Clairmont, Carrie A. Martell, and Maureen L. White Eagle, eds. Sharing our Stories of Survival: Native Women Surviving Violence. Tribal Legal Studies, edited by Gardner, Jerry. Plymouth, United Kingdom: AltaMira Press, 2008.

Gebhardt, Angela and Jane Woody. "American Indian Women and Sexual Assault: Challenges and New Opportunities." Affilia: Journal of 
Women and Social Work 12, no. 3 (August 2012) February 18 2013-237248. doi:10.1177/0886109912452642.

Haag, Ann Murray. "The Indian Boarding School Era and its Continuing Impact on Tribal Families and the Provision of Government Services." Tulsa Law Review 43, (2007-2008): February 16 2013-149-168.

http://simplelink.library.utoronto.ca/ url.cfm/342749

Henry, Terry. "Addressing Violence Against Native American Women and Girls as a Human Rights Issue." New York, United Nations Department of Economic and Social Affairs, January 2012.

http://www.un.org.myaccess.library.u toronto.ca/esa/socdev/unpfii/docum ents/EGM12_Henry.pdf

Klein, Laura F. and Lillian A. Ackerman, eds. Women and Power in Native North America. U.S.A: University of Oklahoma Press, Norman, 1995.

Naughton, Ross. "State Statutes Limiting the Dual Sovereignty Doctrine: Tools for Tribes to Reclaim Criminal Jurisdiction Stripped by Public Law 280." UCLA Law Review 55, (20072008): February 17 2013-489-519. http://simplelink.library.utoronto.ca/ url.cfm/342757

Ramirez, Renya. "Race, Tribal Nation, and Gender: A Native Feminist Approach to Belonging." Meridians: Feminism, Race, Transnationalism 7, no. 2 (January 1 2007): February 19 2013-22-40. doi:10.2979/MER.2007.7.2.22.

Ross, Luana. "From the "F" Word to Indigenous/Feminisms." Wicazo Sa Review 24, no. 2 (October 2009): February 19 2013-39-52. doi:10.1353/wic.0.0041.

Royster, Judith V. "Oliphant and its
Discontents: An Essay Introducing the Case for Reargument Before the American Indian Nations Supreme Court." Kansas Journal of Law and Public Policy 13, no. 1 (2003-2004): February 18 2013-59-68. http://simplelink.library.utoronto.ca/ url.cfm/342763

Smith, Andrea. Conquest: Sexual Violence and American Indian Genocide. Cambridge, MA: South End Press, 2005.

Stapleton, Warren. "Indian Country, Federal Justice: Is the Exercise of Federal Jurisdiction Under the Major Crimes Act Constitutional?" Arizona State Law Journal 29, (1997): February 17 2013337-350.

http://simplelink.library.utoronto.ca/ url.cfm/342756

Torpy, Sally J. "Native American Women and Coerced Sterilization: On the Trail of Tears in the 1970s." American Indian Culture and Research Journal 24, no. 2 (October 1 2007, 2000): February $\quad 16$ 2013-1-22. http://simplelink.library.utoronto.ca/ url.cfm/342753

Weaver, Hilary. "The Colonial Context of Violence: Reflections on Violence in the Lives

of Native American Women." Journal of Interpersonal Violence 24, no. 9 (September 2009): 01/27/20131552-1563

http://journals2.scholarsportal.info. myaccess.library.utoronto.ca/tmp/1 1361919471353892927.pdf 